\title{
Aktualisasi Nilai-Nilai Pendidikan Islam Dalam Membentuk Pola Hidup Sederhana Di Madin Al-Isnaini Montong Wasi
}

\author{
Oleh: Sapril \\ Guru Agama SMPN 1 Keruak Lombok Timur NTB
}

\begin{abstract}
Abstrak: Penelitian yang penulis lakukan ini adalah termasuk dalam penelitian deskriptif. Dalam proses pengumpulan data, penulis menggunakan metode observasi, interview dan dokumentasi. Sedangkan analisis data dalam penelitian ini menggunakan analisis deskriptif kualitatif, yaitu berupa data-data yang tertulis dan hasil wawancara dari berbagai key informan atau sumber informasi tentang perilaku yang diamati, sehingga dengan itu, penulis berupaya mengadakan penelitian yang bersifat deskriptif secara menyeluruh tentang keadaan yang sebenarnya terjadi.
\end{abstract}

Kata Kunci: Aktualisasi Nilai-nilai Keagamaan

Abstract: Research conducted by the author are included in the descriptive study. In the process of data collection, the author uses the method of observation, interview and documentation. Data analysis in this research using qualitative descriptive analysis, namely in the form of data written and interviews from a variety of key informants or sources of information on observed behavior, so with that, the author seeks to conduct descriptive research thoroughly about the actual situation happen.

Keyword: Actualization of Religious Values

\section{PENDAHULUAN}

\section{A. LATAR BELAKANG}

Pendidikan merupakan hal yang sangat penting bagi setiap individu dan masyarakat, Pentingnya pendidikan ini tidak hanya terbatas kepada suatu ummat, bangsa, masyarakat atau pada masa tertentu, tetapi pendidikan mencakup seluruh ummat manusia. Karena dengan pendidikan itulah suatu ummat akan dibawa kepada suatu perubahan-perubahan, baik itu berupa pola pikir, gaya hidup dan lain sebagainya. 
Pendidikan Islam sebagai dasar pembentukan kualitas diri sangat berguna dalam menumbuh kembangkan kesadaran sikap dan prilaku, karena itu nilai pendidikan Islam akan mampu mewujudkan manusia yang diharapkan oleh ajaran Islam yaitu manusia berkeperibadian muslim yang ideal sesuai dengan cita-cita dan pandangan Islam. nilai-nilai pendidikan Islam itu benar-benar menjadi bagian dari peribadinya yang akan menjadi pengendali dalam kehidupannya dikemudian hari atau nilai-nilai pendidikan Islam akan terwujud apabila ajaran Islam itu hidup dan tercermin dalam keperibadian setiap muslim.

Untuk mencapai kehidupan yang bahagia maka manusia ditentukan untuk senantiasa bersyukur terhadap segala nikmat yang telah diberikan Allah, SWT. Dengan memahami dann menerapkan nilai ajaran Islam dalam pola hidup sehari-hari. Umat manusia akan mencapai kehidupan yang bahagia di dunia dan akhirat asalkan manusia menjauhi sifat-sifat boros tetapi tidak kikirterhadap semua nikmat yang dianugrahkan Allah SWT kepada dirinya.

Pola hidup sederhana mengandung unsur kekuatan, ketabahan, pengendalian diri dalam mmenghadapi perjuangan hidup dengan segala kesulitan dan tantangannya. Hidup sederhana semacam mini akan dapat mengembangkan sikap tahu diri, tahu kemampua, dan ketidak mampuannya dalamm berhadapan dalam orang lain (Depag, RI, 2001 : 30).

Salah satu ajaran Islam adalah qona'ah, menurut Hamka dalam tasawuf modern membagi qonaah itu menjadi lima bagian : a). menerima dengan rela apa adanya. b). momohonkan kepada Tuhan tambahan yang pantas, dan berusaha. c) menerima dengan sabar akan ketentuan Tuhan. d) bertaqwa kepada Tuhan dan. e). tidak tertariok oleh tipu daya manusia (Abdul Fatah, 1999 : 66).

Dari lima bagian tersebut kita memahami bahwa qona'ah itu sangatlah luas, menyuruh percaya kepada yang betul-betul akan adanya kekuasaan yang melebihi kekuasaan kita, ,menyuruh sabar menerima ketentuann ilahi jika tidak menyenangkan diri, dan bersyukur jika diberi 
nikmatnya, sebab nikmat itu bisa hilang suatu ketika. bersama dengan itu kita disuruh bekerja, berusaha untuk mencari nikmat itu, kita bekerja bukan lantaran meminta tambahan yang telah ada dan tidak merasa cukup pada apa yang ada dalam tangannya, tetapi kita harus bekerja, sebab orang lain hidup mesti bekerja.

Orang yang qona'ah akan merasa dirinya selalu memiliki ketenangann hidup, lebih-lebih di zaman era globalisasi ini ketenangan hidup merupakan sesuatu yang sangat dibutuhkan manusia, karenan tanpa ketenangan hidup manusia akan nselalu diliputi oleh rasa kegelisahan dan kesusahan, ketenangan itu akan dirasakan oleh seorang bilamana merasa cukup terhadap apa yang yang dimilikinya dan terus berusaha untuk memenuhi kebutuhannya.

Dalam kitab Al-Muntakhobah Fi Al-Mahfuzot disebutkan :

القناعة كنز لايغنى

Artinya : Qona'ah adalah pura (simpanan) yang tak pernah leyap ( Abdul fatah, 1995 : 95)

Seiring dengan kemajuan teknologi dan informasi dewasa ini sangat berdampak bagi, seluruh aspek kehidupan manusia. disatu sisi kemajuan teknologi dan informasi tersebut dapat memberikan keefektifan dan keefensienen bagi umat manusia dalam mejlankan segala aktifitas.. namun disisi lain kemajuan teknologi dan informasi dapat menjadikan manusia jauh dari nilai-nilai dan tatanan sosial yang telah berlaku sehingga melahirkan manusia matrialistik.

Kehidupan modern yang begitu konpetitif menyebabkan manusia harus mengerahkan seluruh pikiran tenaga dan kemampuannya, mereka harus bekerja dann bekerja tanpa mengenal batas dan kepuasan. hasil yang dicapai tak pernah disyukurinya dan selalu merasa kurang, apalagi usaha dan proyeknya gagal, maka dengan mudah ia kehilangan pegangan karena tidak lagi memiliki pegangan yang kokoh bersala dari Tuhan, mereka haya 
berpegang atau bertuhan kepada hal-hal yang bersifat matrial yang sama sekali tidak dapat membimbing hidupnya (Abu Dinata, 2002 : 292).

Dari uraian tersebut diatas dapat kita pahami bahwa emajuan teknologi dan informasi dapat memberikan dampak positif dan negatif bagi umat manusia. dari sisi potisitif kemajuan ntersebut dapat memberikan kemudahan bagi manusia, dengan teknologi dan informasi menjadikan sesuatu yang jauh menjadi dekat dan yang sulit menjadi mudah, sedangkan danpak negatifnya segitu banyak yang apabila informasinya dan teknologi tidak di filter dan di topeng dengan nilai-nilai yang islami maka akan melahirkan manusia-manusia yang memiliki sifat individualistic dan matrialistik.

Sehubungan dengan itu Zuhairini dalam bukunya metode pendidikan Islam mengatakan : Islam sebagai agama, sebagai jalan hidup, tentunya akan memberikan jawaban tentang berbagai macam permasalahana hidup dan kehidupan manusia dan memberikan petunjuk dan jalan hudup bagi manusia dalam menuju kepada tujuan hidupnya (Zuhairini, 1977 : 22).

Islam akan nmemberikan berbagai macam solusi kepada umat manusia tentang berbagai macam masalah yang dihadapi sehingga permasalahan yang dihadapinya akan menemukan titik terang dan tidak akan mengalami hal-hal yang menjadi beban yang berkepanjangan dan menimbulkan penyakit sosial yang selama ini menjadi penyakit masyarakat modern.

Bertolah dari latar belakang diatas, maka penulis sangat tertarik untuk menyusun Penelitian dengan judul : PERANAN NILAI-NILAI PENDIDIKAN ISLAM DALAM MEMBENTUK POLA HIDUP SEDERHANA DI MADIN AL-ISNAINI MONTONG WASI KAB. LOMBOK TIMUR

\section{B. RUMUSAN MASALAH}


Berpijak dari apa yang penulis paparkan dalam latar belakang tersebut ada beberapa hal yang penulis jadikan sebagai rumusan masalah yaitu :

a. Bagaimanakah bentuk upaya pola hidup sederhana siswa di MADIN AlIsnaini Montong Wasi

b. Bagimanakah bentuk-bentuk pelaksanaan pola hidup sederhana siswa di MADIN Al-Isnaini Montong Wasi

c. Bagaimanakah peran nilai-nilai pendidikan Islam dalam membentuk pola hidup sederhana siswa di MADIN Al-Isnaini Montong Wasi

\section{METODOLOGI PENELITIAN}

\section{A. PENDEKATAN PENELITIAN}

Dengan memahami dan menganalisis permasalahan yang ada, maka dalam penelitian ini memakai penelitian kualitatif yang lebih banyak menggunakan logika serta penjelasan-penjelasan serta data-data dari sumber yang diteliti dilapangan.

Jenis penelitian ini bersifat etno metodologi yaitu metode pengumpulan data dengan menunjuk pada mata pelajaran yang akan diteliti. Meneliti permasalahan-permasalahan yang berkaitan dengan peranan nilainilai pendidikan agama Islam dalam membentuk pola hidup sederhana di MADIN Al-Isnaini Montong Wasi. 38

Menurut Borgan dan Tailor dalam bukunya Moleong mendefinisikan "Penelitian kualitatif sebagai prosedur penelitian yang menghasilkan data deskriftif berupa kata-kata tertulis atau lisan dari orang-orang dan prilaku dari orang yang dapat diamati". 39

Sedangkan Kirk dan Muller mendefinisikan bahwa "Penelitian kualitatif adalah tradisi tertentu dalam ilmu pengetahuan sosial yang secara fundamental yang bergantung pada pengamatan manusia dalam

38 Moleong, $2002: 15$

39 Ibid $2002: 3$ 
kawasannya sendiri dan berhubungan dengan orang-orang tertentu dalam bahasanya dan pristilahannya. ${ }^{40}$

Penelitian kualitatif merupakan suatu pendekatan yang berdasarkan pada penjelasan dan data-data yang diambil langsung dari obyek penelitian secara menyeluruh.

Dalam penelitian ini menggunakan metode kualitatif dengan alasan pertama, metode kualitatif lebih mudah mengadakan penelitian yang hanya berbentuk penjelasan dan data-data. Kedua, metode ini lebih mudah menyajikan hasil penelitian secara langsung antara peneliti dengan responden. dan ketiga, metode ini lebih peka terhadap pola-pola nilai yang dihadapi.

\section{B. SUMBER DATA}

Menurut Arikunto yang dimaksud dengan sumber data dalam penelitian adalah subyek darimana dapat di peroleh. ${ }^{41}$

Sedangkan menurut Lopland dalam Moleong menyebutkan "Sumber data utama dalam penelitian kualitatif berupa kata-kata dan tindakan, selebihnya adalah data tambahan seperti dokumen dan lain-lain. ${ }^{42}$

Untuk mendapatkan sejumlah data dan dokumen-dokumen yang diperlukan, tentu peneliti bertemu langsung dengan orang-orang yang dimintai keterangan sehubungan dengan obyek penelitian yang dimaksud, di antaranya adalah : Kepala sekolah, (Hjh. B. Nurhayati) sebagai pemegang pimpinan MADIN Al-Isnaini Montong Wasi.

\section{METODE PENGUMPULAN DATA}

Adapun metode yang digunakan dalam mengumpulkan data-data anatara lain :

1. Metode Observasi

\footnotetext{
40 Ibid $2002: 3$

41 Suharsimi Atikunto, 2002 : 107

42 Ibid, 2002 : 112
} 
Metode observasi sesungguhnya suatu strategi pengumpulan data dalam bentuk sederhana, praktis dan tidak terlalu banyak menghabiskan dana dan waktu karena pelaksanaannya langsung dengan pengamatan terhadap pristiwa-pristiwa yang ada di lapangan.

Menurut Margono "bahwa metode observasi merupakan pengamatan dan pencatatan secara sistimatis terhadap gejala yang tampak pada obyek penelitian. Jadi metode pengumpulan data dengan cara terjun langsung ke lapangan untuk mengamati berbagai pristiwa sekaligus mengadakan pencatatan secara sistimatis terhadap segala hal yang ditemukan agar data yang diperoleh tidak dilupakan. 43

Dalam menggunakan observasi langsung, yaitu pengambilan data dengan mempergunakan indra penglihatan (mata) dan menyelidiki obyek yang sedang diteliti dengan harapan agar mendapat hasil yang lebih akurat.

2. Metode Dokumentasi

Metode dokumentasi untuk mencari data mengenai hal-hal atau variabel berupa catatan, transkrip, buku, surat kabar, majalah, prasastri, notulen rapat, lengger, agenda dan sebagainya. ${ }^{44}$

Sedangkan menurut Guba dan Lincol dalam Moleong mendefinisikan " Dokumentasi adalah setiap bahan tertulis ataupun film. Mengumpulkan data melalui peninggalan tertulis, seperti arsiparsip dan termasuk juga buku-buku tentang pendapat, teori, dalil atau hukum-hukum dan lain yang berhubungan dengan masalah penelitian. ${ }^{45}$ Adapun data yang diperoleh melalui metode ini antara lain : data sejarah berdiri MADIN Al-Isnaini Montong Wasi, keadaan MADIN AlIsnaini Montong Wasi, struktur organisasi MADIN Al-Isnaini Montong Wasi, data keadaan guru, data Sarana dan prasarana dan lain-lain.

3. Metode Interview

${ }^{43}$ Margono, $2004: 158$

${ }^{44}$ Arikunto, $2002: 206$.

45 Margono, 2004 : 181. 
Wawancara adalah alat pengumpul informasi dengan cara mengajukan sejumlah pertanyaan secara lisan untuk dijawab sacara lisan pula. Wawancara adalah " Percakapan dengan maksud tertentu dilakukan oleh dua belah pihak yaitu pewawancara dan yang di wawancarai 46

Hubungannya dengan metode ini, dapat disimpulkan data antara lain : Letak geografis MADIN Al-Isnaini Montong Wasi, pelaksanaan proses pendidikan Agama Islam, dan problematika yang dihadapi dalam membentuk pola hidup sederhana di MADIN Al-Isnaini Montong Wasi.

4. Metode Kepustakaan

Metode kepustakaan adalah suatu cara untuk mengumpulkan data dan memperoleh informasi dengan mengunjungi perpustakaan atau dengan kata lain suatu cara pengumpulan data dengan membaca bukubuku literatur yang berkaitan dengan materi pembahasan. Metode ini dipergunakan untuk mengumpulkan data yang sifatnya teoritis.

\section{E. METODE ANALISA DATA}

Menurut Bagdan dan Taylor dalam bukunya mendefinisikan analisis data "sebagai proses yang merinci usaha secara formal untuk menentukan tema dan merumuskan hipotesis (Ide) berdasarkan data dan sebagai usaha untuk memberikan bantuan pada tema dan hipotesis itu". ${ }^{47}$

Setelah memperoleh data yang valid, kemudian dianalisis dengan tiga cara, yaitu :

1. Persiapan

Kegiatan dalam langkah persiapan ini antara lain :

a. Memeriksa kembali data yang diperoleh, apakah data tersebut dapat di pertanggung jawabkan atau tidak.

46 Margono, $2004: 165$.

${ }^{47}$ Moleong, $2002: 103$ 
b. Memeriksa kelengkapan data, yaitu mengecek data-data yang telah dikumpulkan dari lokasi penelitian serta meneliti data-data yang dibutuhkan dalam penelitian.

2. Tabulasi data (pengelompokan)

Dalam hal ini, data yang di kelompokkan sesuai dengan variabelvariabel yang telah dikumpulkan di lapangan.

3. Penerapan data sesuai dengan pendekatan ilmiah

Pengolahan data yang telah diperoleh dengan menggunakan aturan-aturan yang ada sesuai dengan metode penelitian yang digunakan. Dalam penerapan data ini, mengacu pada metode poenelitian kualitatif yang mana data dimaksud akan disajikan pada bab selanjutnya.

Didalam menganalisis data dalam hal ini penulis menggunakan metode induksi dan deduksi.

Metode deduksi adalah suatau jalan berpikir dari hal yang sifatnya umum kemudian dikenakan kepada suatu yang sifatnya khusus. Melalui metode ini penulis gunakan untuk mempelajari masalahmasalah yang sifatnya umum baru kemudian ditarik kesimpulan atau pengetahuan yang bersifat khusus.

Metode Induksi, kebalikan dari metode deduksi yang bersifat Induksi (induktif) adalah : "Berangkat dari fakta- fakta yang khusus, pristiwa-pristiwa yang konkrit, kemudian fakta-fakta atau pristiwapristiwa yang khusus konkrit itu ditarik generalisasi-generalisasi yang mempunyai sifat umum. Jadi melalui metode yang bersifat induksi (induktif) ini diadakan penganalisaan data- data dari suatu hal yang sifatnya khusus terjadi, dianalisa melalui suatu pemikiran yang dapat memberikan suatu kesimpulan. 


\section{LAPORAN HASIL PENELITIAN}

\section{A. BENTUK-BENTUK POLA HIDUP SEDERHANA DI MADIN AL-ISNAINI MONTONG WASI}

Bentuk-bentuk pelaksanaan hidup sederhana dapat kita lihat dalam kehidupan sehari-hari para santri seperti yang dilakukan oleh H.LL. Moh Fahri sebagai pengurus pondok pesantren sebagai berikut : "Bentuk pelaksanaan pola hidup sederhana sehari-hari para santri pertama, segi makan minum, sedikit makan (Qolilul akli) tidak banyak makan, terutama mereka yang tahfiz karena banyak makan cepat ngantuk. kedua, cara berpakaian, tidak boleh memakai pakaian singlet di luar kamar, kalau didalam kamar dibolehkan, sederhana tapi sopan, Ketiga, tingkah laku, dari segi gaya hidupnya berpenampilantidak menampilkan rasa sombong artinya bersifat tawadduk" 60

Kemudian bentuk-bentuk pelaksanaan pola hidup sederhana terlihat dalam kehidupan sehari-hari para siswa-siswi/santri sebagaimana hasil wawancara penulis dengann beberapa siswa-siswi/santri sebagai berikut :

1. Makan Minum

Dalam hal makan minum para siswa-siswi/santri tidak diberikan melakukan aktivitas yang terlalu banyak untuk mengurus makan minum sebagaimana yang dilakukan oleh Muhammad Khabir kelas II : "para santri haya diberikan waktu untuk memasak haya satu kali dan itupun waktunya haya sedikit yaitu 20 menit. Para santripun tidak semua melakukan kegiatan memasak karena sesuatu dann lain hal sehingga yang sudah memasak memberikan masakannya kepada yang belum masakhingga persiapan langsung habis dan tidak ada kesempatan untuk masak lagi sehingga para santri kadang-kadang makan satu kali sehari dan lkauknya dengann biji-biijian"

60 (Wawancara, 20 Juni 2015). 
Senada dengan itu, saeful Ali Bahtiar Kelas III mengatakan : "Masalah makanan cukup sederhana yaitu tidak terlalu keying sedangsedang saja dan bila kita makan 2 kali sehari, kadang-kadang bisa satu kali yang penting bisa menghilangkan lapar dan sebagai bekal kita ke sekolah, karena sebaik-baik perkara yang sedang-sedang saja"

Sejalan dengan itu juga, Lalau Ridwan kelas III mengatakan : "Saya makan setiap hari 2 kali sehari kadang-kadang 1 kali sehari dan makanannya sedikit, kita dilarang makan yang berlebihan" 61

2. Pakaian

Dalam hal berpakaian para siswa-siswi/santri sangat sederhana sebagaimana yang diungkapkan oleh Suhardi kela III : “Dalam rangka memperhatikan ajaran Islam yaitu hidup sederhana maka kami dari santri memakai pakaian yang sederhana misalnya pakaian yang sudah lama kayak baju rombengan kadang-kadang saya melihat ada yang memakai pakaian yang sudah robek dan kelihatan sudah agak lusuh seperti itulah bentuk kesederhanaan dalam sehari-hari

Senada dengan itu Suriatun mengatakana : "dan masalah berpakaian sederhana, tapi walaupun pakaian kita sederhana yang penting sopan dan wajar aja dan disini kita dilarang berpakaian yang tidak bisa menutupi aurat begitu juga sebaliknya"

Hal itu juga diungkapkan oleh Lalu Turmuzi : “Cara berpakaian sopan dan kita dilarang berpakaian yang mewah seperti di rumah" 62

3. Tingkah laku

Dalam masalah tingkah laku terlihat dalam kehidupan sehari-hari sebagaimana yang dikatakan oleh LL. Yusuf Sudarman kelas III : "dalam pergaulan sehari-hari sesama santri dan santriwati secara khusus kami tidak tau tingkah laku yang sebenarnya namun secara umum baik dari tutur kata atau perbuatannya mereka sehari-hari, mereka membiasakan diri untuk bertingkah laku secara agama misalnya : tidak suka mencaci

61 (Wawancara, 21 Juni 2015).

62 (Wawancara, 21 Juni 2015). 
maki temannya dalam ucapan, tidak suka saling sepak terjang dalam perbuatan dan lain-lain.

Sejalan dengan itu, Nirmala kelas III mengungkapkan : “Masalah tingkah laku kita disini Alhamdulillah cukup baik karena berkat bimbingan usta. Hal itu juga dikatakan oleh L Putrawan kelas III : “Tingkah laku di pondok pesantren tidak terlalu bebas kelakuan kita haya sebatas pondok saya ingat dari perkataan masih kurang kita banyak memakai bahasa sendiri itulah anak pondok seperti kami ini" 63

bentuk-bentuk pola hidup sederhana di MADIN Al-Isnaini Montong Wasi yang bernaung di Pondok Pesantren Darul Hamidin Padamara dapat diketahui dan nterlihat dalam cara hidup mereka yang sederhana dalam setiap keadaan dan dalam segala hal. Seperti dalam makan minum berpakaian yang sederhana atau tidak berlebihan atau mencolok dan dari segi tingkah laku / akhlak.

\section{B. NILAI-NILAI PENDIDIKAN ISLAM YANG MENCERMINKAN POLA HIDUP SEDERHANA DI MADIN AL-ISNAINI MONTONG WASI}

MADIN Al-Isnaini Montong Wasi merupakan sebab lembaga pendidikan yang bernuansa agama yang menanamkann nilai-nilai Islami dan pola hidup sederhana. yang sebagaimana yang dikatakan Susiana, S.Pd salah seorang pembina pondok pesantren mengatakan bahwa : "Untuk membentuk peribadi muslim di pondok pesantren supayatidak sombong, hidup sederhana, bertanggung jwab, tidak berpoya-poya dan mensyukuri nikmat yang diberikan oleh Allah SWT harus melalui jalur pendidikan Islam. 64

Pernyataan diatas dapat dibuktikan berdasarkan hasil pengamatan dan observasi yang dilakukan peneliti bahwa : "melihat perilaku dan keseharian siswa-siswi/santri MADIN Al-Isnaini Montong Wasi betul-betul terlihat atau nampak sekali dalam keseharian dan kebersamaan mereka yang

63 Wawancara, 22 Juni 2015.

64 Wawancara, 23 Juni 2015. 
bersifat umum. demikian juga dalam hal kemandirian mereka betul-betul menampakkan pola hidup sederhana dalam hal yang bersifat khusus.

Memahami nilai-nilai pendidikan Islam dalam membentuk pola hidup sederhana di pondok pesantren bukan sederhana tampa membuka lembaran sejarah mengenai yang begitu besar dan yang bermanfaat terhadap sikap dan perilaku umatnya.

Apabila penulis cermati atau dapat menanyakan bahwa kehidupan pesantren mengandung nilai-nilai Islam yang sangat esensial bagi keselamatan umat manusia, untuk melihat dan mendidik diri manusia untuk menjadi manusia yang dapat memberikan manfaat dan membawa rahmat terutama untuk dirinya sendiri, ,bagi orang lain maupun bagi alam semesta.

Berdasarkan hasil pengamatan peneliti bahwa pesantren memiliki fungsi ganda antara lain :

1. Sebagai lembaga pendidikan keagamaan yang berfungsi untuk menyebarluaskan ilmu-ilmu agama

2. Pesantren berfungsi juga sebagai lembaga pengkaderan yang mampu mencetak kader umat dan bangsa atau menjadi pemimpin dalam berbagai bidang kehidupan

3. Pesantrenn juga berfungsi sebagai agen reformasi sosial yang emnciptakan perubahan dan perbaikan masyarakat. ${ }^{64}$

Pesantren sebagai wadah pendidikan Islamtelah memberikan teladan yang sangat baik dan yang paling nyata dalamm berbagai hal kehidupan manusia sehari-hari, disamping itu juga pesantren selalu memberikan penjelasan-poenjelasan yang bernilai ibadah terhadap umatnya, agar dapat tetap mempertahankan serta berkomitmen terhadap kualitas imannya kepada Allah SWT.

Didalam pesantren siswa-siswi/santri tidak haya belajar saja, tetapi juga lebih diarahkan kepada pembinaan terhadap mentalitas santri dalam

${ }^{64}$ Observasi, 27 Juni 2015. 
kehidupan pesantren. mereka harus menerima kenyataan yang terkoordinasi dengann kehidupan di pesantren, hal ini dilakukan supaya siswasiswi/santri berhasil dalam proses pendidikan dan apa yang diharapkan akan terwujud dengan menerapkan nilai-nilai kesilaman dalam sehari-hari.

Keberhasilan suatu pondok pesantren akan terlihat apabila dalam kehiduapan sehari-hari dilingkungan pesantren selalu ditanamkan dan dijalankan nilai-nilai keislaman baik dalam hubungannya dengan sang kholik (habluminalllah) maupun hubungannya dengan sesama manusia (habluminannas) dalam intraksi sosial bagi seorang pribadi baik sesama santri, dengan para asatiz maupun dengan masyarakat sekitarnya.

\section{SIMPULAN}

Dari hasil pokok penelitian diatas, selanjutnya peneliti dapat menyimpulkan sebagai berikut :

1. Upaya pembentukan pola hidup sederhana di MADIN Al-Isnaini Montong Wasi adalah melalui pembinaan dalam bentuk pengajian, contoh tauladan dari guru dan ada kontrol langsung dari ustaz

2. Bentuk pelaksanaan pola hidup sederhana
a. Cara berpakaian yang sederhana
b. Makan minum yang tidak berlebihan
c. Kepedulian sosial sesama santri

3. Nilai-nilai pendidikan Islam dalam membentuk pola hidup sederhana di MADIN Al-Isnaini Montong Wasi ialah nilai-nilai pendidikan Islam yang mencerminkan pengamalan Al-Qur'an dan sunnah melalui cara berpakaian, makan minum, dan perilaku sehari-hari.

\section{DAFTAR PUSTAKA}

Abdul fatah, 1995, Kehidupan manusia ditengah "alam materi" (Jakarta, PT. Remja Cipta.

Abu Dinata, 2002, Akhlak tasauf, Jakarta, PT. Raja Grafindo Persada, 
Al-Hasimi, Imam, 1979, Terjemah Mukhtarul Hadits, Pustaka Setia, Bandung Azra, Azyumardi. 2002. Pendidikan Islam, Logos Wacara Ilmu, Ciputat Arikunto. Suharsimi, 1989, Pengantar Dasar-dasar Penelitian, Bina Aksara, Jakarta 1991, Prosedur Penelitian, Rineka Cipta, Jakarta 2002, Prosedur Penelitian suatu pendekatan Praktek, Rineka Cipta, Jakarta

Bahresiy, Salim, 1987, Terjemah Riadusshalihin, PT. Al- Ma'arif, Bandung

Tim-Dosen FIP-I Malang, Pengatar Dasar-Dasar Kependidikan, Suryabrata, Usaha Nasional

UUD RI, 45, 2000, Pustaka Agung Harapan, Surabaya

Uhbiyati, Nur 1999, Ilmu Pendidikan Islam, Pustaka Setia, Bandung

Moleong, Lexy, J, 2002. Metodologi Penelitian Kualitatif, Remaja Rosda Karya, Bandung

Departemen Agama RI, 1990, Al-Qur'an Dan Terjemah, CV. Jaya Sakti Surabaya. Yunan Nasution, 1988, Islam dan problem-problem kemasyarakatan, Jakarta, Bulan bintang

Zuhairini, Abdul Ghafur, Slamet.1977. Filsafat Pendidikan Islam, Jakarta, Bumi Aksara, Jakarta 